\title{
Makna dan Perilaku Pengguna Komunikasi Budaya Digital di Kabupaten Garut - Jawa Barat
}

\author{
Zikri Fachrul Nurhadi \\ Program Studi Ilmu Komunikasi, Universitas Garut, Indonesia \\ zikri_fn@uniga.ac.id
}

\begin{abstract}
This study aims to explain the motives, experiences, meaning and behavior for users of digital culture communication. This research method using qualitative approach through participant observation, depth interview, and literature study. Informant research is academic, entrepreneur, student and humanist with purposive sampling technique amounted five persons. The surgical blade used by phenomenology theory explains the structure of the conscious experience, studying the form of experience from the point of view of the person who experienced it directly. The results showed that the motive for using digital culture communication is various constituents, enthusiasts, easy communication process, economic benefits, while the motive to seek information, rapid acceleration of friendship, connect with the community, family gathering. Likewise communication experience can feel the difference between analog culture and digital culture, nihilism characterizes the communication of digital culture. While the meaning for users of digital culture communications is efficient, represented, profession and existence, while the user behavior of digital culture communication is divided into offline categories (hospitality, meeting, face to face), online (hoax alert, chat, online shopping).
\end{abstract}

Keywords: Digital Communication, Meaning, Behavior, Phenomenology

\begin{abstract}
Abstrak
Penelitian ini bertujuan untuk menjelaskan motif, pengalaman, makna dan perilaku bagi pengguna komunikasi budaya digital. Metode penelitian ini menggunakan pendekatan kualitatif melalui observasi partisipan, wawancara mendalam, dan studi pustaka. Informan penelitian adalah akademisi, wirausaha, mahasiswa dan budayawan dengan teknik purposive sampling berjumlah lima orang. Pisau bedah yang digunakan adalah teori fenomenologi untuk menjelaskan struktur pengalaman sadar, dan mempelajari bentuk pengalaman dari sudut pandang orang yang mengalaminya langsung. Hasil penelitian menunjukkan, motif menggunakan komunikasi budaya digital beragam konstituen, peminat, proses komunikasi mudah, manfaat ekonomis, sedangkan motifnya adalah untuk mencari informasi, akselerasi pertemanan yang cepat, berhubungan dengan komunitas, silaturahmi keluarga. Begitupun, pengalaman komunikasi bisa merasakan perbedaan budaya analog dan budaya digital, nihilisme menjadi ciri komunikasi budaya digital. Sedangkan makna bagi pengguna komunikasi budaya digital adalah efisien, terwakili, profesi dan eksistensi, sementara perilaku pengguna komunikasi budaya digital dibagi dalam kategori offline (silaturahmi, rapat, face to face), online (waspada hoax, chatting, belanja online).
\end{abstract}

Kata kunci: Komunikasi Digital, Makna, Perilaku, Fenomenologi

Copyright $\odot 2018$ Ikatan Sarjana Komunikasi Indonesia. All rights reserved

\section{PENDAHULUAN}

Perkembangan teknologi digital muncul begitu pesat, sehingga penyerapannya masuk semakin dalam ke seluruh lapisan masyarakat sebagai sarana interaksi dan pencarian informasi. Penggunaan teknologi digital dengan mengakses internet melalui perangkat bergerak (mobile gadget) telah banyak dilakukan oleh masyarakat, mulai dari social networking hingga ke mobile banking, mendapatkan news hingga shopping (Rianto, 2016; Stellarosa, 2017). Fenomena partisipasi aktif masyarakat tersebut, memunculkan perbedaan pada perilaku individu dan ungkapan makna komunikasi bermedia dalam keseharian hidupnya sehingga mempengaruhi landscape berkomunikasi masyarakatnya. 
Perkembangan mengagumkan dari teknologi komunikasi terkait dampak pada perilaku telah menarik minat Google dan perusahaan riset pasar, TNS-Australia, baru-baru ini mereka merilis hasil studi tentang tingkah laku pengguna smartphone didelapan negara di Asia Pasifik, yaitu Indonesia, Singapura, India, Jepang, Australia, Taiwan, HongKong dan Korea Selatan. Riset digelar pada Juni 2015 dan dipublikasikan pada November 2015. Melalui survei yang melibatkan 1.000 responden di negara-negara tersebut, terungkap beberapa fakta menarik mengenai tingkah laku pengguna smartphone. Berdasarkan hasil studi tersebut, penyerapan smartphone paling tinggi terjadi di Singapura sebesar 88\%, yang disusul oleh Korea Selatan sebanyak $83 \%$ dan Hong Kong 79\%. Sedangkan di Indonesia, penetrasi smartphone baru mencapai $43 \%$ saja. Walau begitu angka penetrasi di Indonesia merupakan yang tertinggi di kawasan Asia Tenggara. Hampir 50\% pemilik smartphone di Indonesia menjadikan peranti, itu sebagai peralatan telekomunikasi utama, termasuk untuk mengakses internet.

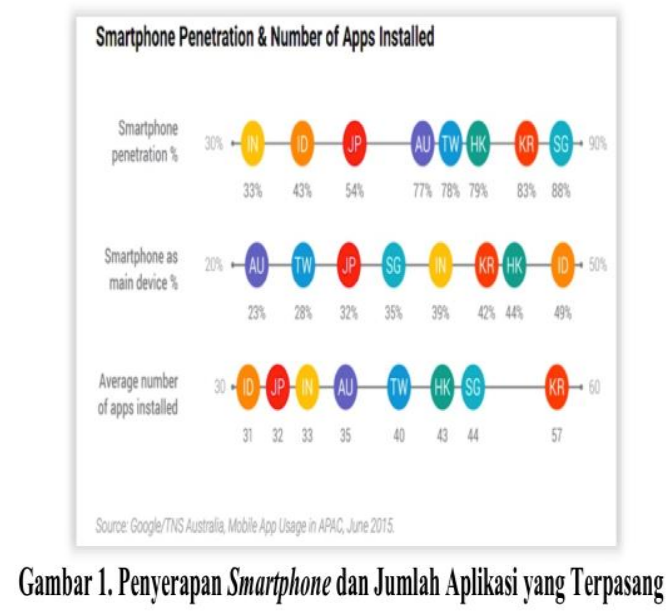

Selain jumlah penyerapan smartphone, rata-rata pengguna smartphone di Korea Selatan menyematkan 57 aplikasi pada smartphone mereka dan membuat negara ini menempati posisi puncak, disusul oleh Singapura dan Hong Kong. Sedangkan Indonesia berada di urutan akhir dengan rata-rata 31 aplikasi yang terpasang pada smartphone. Hasil riset tersebut juga mengungkapkan terdapat tiga kategori aplikasi yang paling sering digunakan sehari-hari di setiap negara, yaitu: (1) Aplikasi yang berhubungan dengan aktivitas media social; (2). Aplikasi chatting, seperti WhatsApp, WeChat, dan Line; (3) Aplikasi baca berita dan mesin pencari.

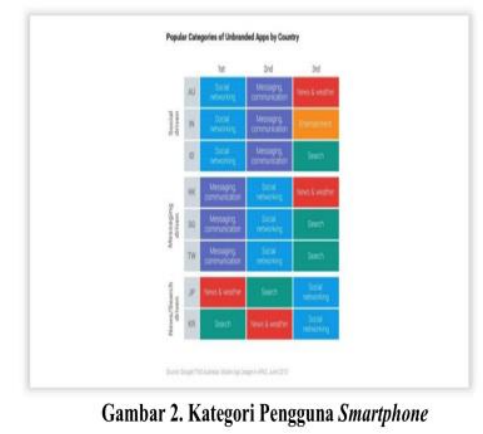

Berdasarkan hasil studi tersebut, kategori yang paling laris di Indonesia adalah aplikasi media sosial (seperti Facebook, Twitter, atau Path), disusul oleh aplikasi chatting dan aplikasi mesin pencari. Masao Kakihara, Senior Research Manager Market Insight Google Asia Pasific, dalam blog Google, mengatakan "smartphone sangat penting untuk aktivitas mereka sehari-hari, kalaupun mereka punya peranti telekomunikasi kedua, seperti komputer pribadi maupun tablet, akses ke dunia maya tetap dilakukan lewat 
peranti berlayar lebih kecil, di pasar Asia, hanya tiga aplikasi yang laku, yaitu instant messaging (whatsapp atau line), media sosial, dan mesin pencari”, ungkap Masao. Riset Google mendapati pemilik smartphone ketiga negara dikategorikan sebagai kelompok "social driven", dari tiga indikator utama pemakaian smartphone untuk menjelajah dunia maya, ketiga negara didominasi aktivitas media sosial di peringkat pertama dan chat di peringkat kedua. Di peringkat ketiga indikator, pengguna Indonesia didominasi aktivitas "gugling". Adapun peringkat ketiga aktivitas internet di India adalah mencari hiburan, sementara Australia untuk mencari berita dan kabar cuaca.

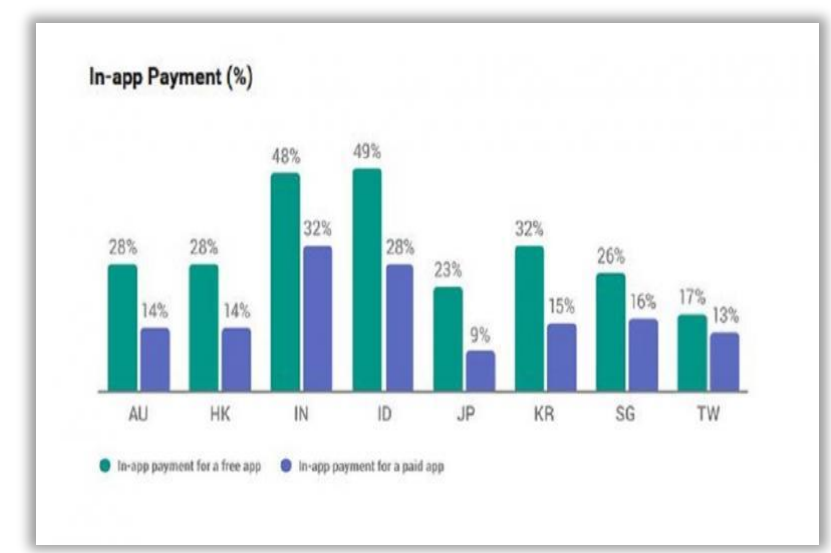

Gambar 3. Blog Google Peta Situs Hasil Riset Google dan TNS Australia pada Juni 2015

Fakta lain dari survei itu, situs yang paling laris dibuka di Indonesia adalah aplikasi belanja online, hiburan, dan travel. Data ini persis sama dengan hasil survei di India. Aplikasi keuangan hanya laris dibuka di Taiwan dan Korea, sementara situs restoran laku di Hongkong dan Taiwan. Khusus Singapura, hanya situs travel yang laku. Dari hasil riset Google bersama TNS Australia tersebut, sejumlah peluang membentang. Peluang itu datang mulai dari bisnis aplikasi hingga segmen penggunaannya.

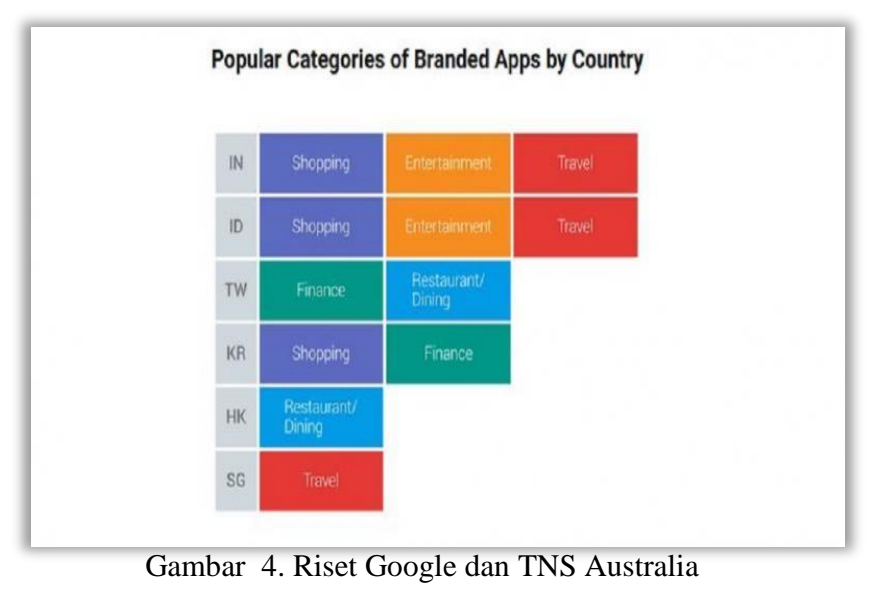

Meski begitu, hasil studi tersebut bukan berarti 100 persen akurat, setidaknya sudah bisa menjadi gambaran tentang tingkah laku pengguna smartphone di Asia Pasifik, khususnya Indonesia. Survei lain yang dirilis bulan Oktober 2016, yaitu tentang penggunaan internet di Indonesia, dilakukan oleh Asosiasi Penyelenggara Jasa Internet Indonesia (APJII), diketahui jumlah pengguna internet di Indonesia sudah mencapai 132,7 juta dari populasi penduduk Indonesia saat ini 256,2 juta orang, dari angka pengguna tersebut, sebanyak $47,5 \%$ pengguna internet adalah wanita, sedangkan $52,5 \%$ adalah pria. Masih menurut survei tersebut, $65 \%$ atau sekitar 86,3 juta pengguna internet di Indonesia berada di Pulau Jawa. Adapun di luar Jawa, pengguna internet Indonesia berturut-turut tersebar paling banyak di Sumatera, Sulawesi, Kalimantan, Bali dan Nusa, serta Maluku dan Papua. 
Kegandrungan penduduk Indonesia terhadap internet dan media sosial sejalan dengan hasil survei yang dilakukan oleh Asosiasi Penyelenggara Jasa Internet Indonesia (APJII). Menurut Semuel A. Pangerapan, Ketua Umum APJII, peningkatan tersebut tak lepas dari semakin populernya media sosial seperti Facebook, Twitter, Path, Instagram dan sejenisnya. Hal ini, terlihat jelas dari survei yang pernah dilakukan asosiasi tersebut bekerjasama dengan Puskakom UI mensurvei 7.000 pengguna internet dari berbagai provinsi, di mana diantaranya diberikan pertanyaan yang lebih detil mengenai apa saja yang mereka lakukan dengan internet. Hasilnya, sebanyak 87,4 persen dari total koresponden mengaku gemar mengakses media sosial. Sementara kegemaran lainnya yakni melakukan riset dan mencari data melalui mesin pencari dilakukan 68,7 persen koresponden.

Hal yang sama juga terlihat pada perilaku mahasiswa di Universitas Garut yang menggunakan perangkat komunikasi melalui saluran internet baik menggunakan laptop untuk aktivitas searching dan terutama smartphone untuk berkomunikasi kepada sesama mahasiswa melalui beragam aplikasi (Instagram, Facebook, Path, Whatsapp) dan kepada dosennya didalam group. Internet dan smartphone bukanlah satusatunya pasangan teknologi komunikasi dalam membangun masyarakat informasi, ada teknologi berbentuk Personal Computer (PC) yang kini tak pelak mendominasi hampir semua ruang hidup manusia setelah penemuannya di tahun 1946 hingga sekarang, oleh karena kemampuannya untuk melaksanakan banyak tugas (task), maka pantas jika computer yang kini berevolusi baik bentuk dan penamaannya menjadi laptop dan notebook adalah penemuan yang paling mutakhir dan berpengaruh pada kehidupan manusia.

Sejak awal pengembangannya, teknologi ini telah bersinggungan dengan bidang komunikasi, dalam judul kajian ini "makna dan perilaku komunikasi budaya digital" maka yang di amati adalah perilaku komunikasi manusianya, yang terjadi dalam suatu lingkungan masyarakat yang telah mengadopsi teknologi komunikasi dari berbagai aplikasi komunikasi yang sudah kita kenal, seperti e-mail, chatting, blackberry messenger, media social, game multiplayer, blog, web dan cara individu memaknai media komunikasi berbasis digital yang digunakan dalam interaksi manusia. Bidang kajian ilmu komunikasi sebagai salah satu ilmu pengetahuan social, pada dasarnya difokuskan pada pemahaman tentang tingkah laku manusia dalam mempertukarkan dan menginterpretasikan pesan-pesan untuk menciptakan makna.

Perilaku berkomunikasi di Indonesia khususnya masyarakat di Kabupaten Garut kekinian tak lepas dari atmosfer yang dimulai sejak beberapa puluh tahun lalu ketika pusat gelombang perubahan sosial yang didominasi oleh teknologi komunikasi di Amerika Serikat. Apa yang terjadi merupakan dorongan perubahan sosial dalam masyarakat, khususnya komputer dan internet menjadi elemen penting terbentuknya masyarakat baru, suatu masyarakat yang mengadopsi dan menggunakan teknologi dalam berkomunikasi. Kehadiran teknologi informasi dan komunikasi memberikan makna akan kelahiran budaya dan tatanan sosial yang baru, dari Masyarakat Agraris menjadi Masyarakat Informasi. Kabupaten Garut sebagai daerah penyangga Ibu Kota Jawa Barat tak luput dari arus perubahan budaya dari masyarakat informasi berbasis digital yang dimiliki daerah perkotaan, mempengaruhi daerah lain karena adanya urbanisasi. Terkait dengan fenomena yang telah dijelaskan, maka penulis berusaha mengungkapkan bagaimana fenomena komunikasi menggunakan teknologi digital dengan judul: Komunikasi Budaya Digital (Studi Fenomenologi tentang Makna dan Perilaku komunikasi.

\section{KERANGKA TEORITIS}

Kerangka teoretis pada kajian ini menggunakan teori Fenomenologi, yaitu cara membangun pemahaman tentang realitas. Pemahaman tersebut dibangun dari sudut pandang para aktor sosial yang mengalami peristiwa dalam kehidupannya. Pemahaman yang dicapai dalam tataran personal merupakan konstruksi personal realitas atau konstruksi subjektivitas (Nurhadi, 2015). Tujuan utama fenomenologi adalah mempelajari bagaimana fenomena dialami dalam kesadaran, pikiran, dan dalam tindakan, seperti bagaimana fenomena tersebut bernilai atau diterima secara estetis. Fenomenologi mencoba mencari pemahaman bagaimana manusia mengkonstruksi makna dan konsep-konsep penting, dalam kerangka intersubjektivitas. Penelitian fenomenologi pada kajian ini mencoba menjelaskan atau mengungkap makna dan perilaku pengguna komunikasi digital dengan konsep atau fenomena pengalaman yang didasari oleh 
kesadaran yang terjadi pada beberapa individu. Penelitian ini dilakukan dalam situasi yang alami, sehingga tidak ada batasan dalam memaknai atau memahami fenomena yang dikaji (Creswell, 2002).

\section{METODE PENELITIAN}

Penelitian ini menggunakan pendekatan kualitatif yang menitikberatkan pada observasi partisipan dan suasana ilmiah (natural setting). Terkait dengan judul komunikasi digital tentang makna dan perilaku komunikasi digital khususnya di Kabupaten Garut, peneliti dapat mempelajari bentuk motif, pengalaman dan makna dari para pengguna komunikasi budaya digital dari sudut pandang orang yang mengalaminya langsung. Pemilihan pengguna ini didasarkan kepada pengguna yang mampu menggambarkan kembali fenomenanya yang telah dialaminya terutama dalam sifat alamiah motif dan maknanya, bersedia untuk terlibat dalam kegiatan penelitian, serta bersedia untuk diwawancara dan direkam aktivitasnya selama wawancara atau selama penelitian berlangsung.

Adapun kriteria pemilihan informan menggunakan purposive sampling. Menurut Kriyantono (2006: 158) menyatakan bahwa: teknik ini mencakup orang-orang yang diseleksi atas dasar kriteria-kriteria tertentu yang dibuat periset berdasarkan tujuan riset. Adapun jumlah pengguna pada kajian ini sebanyak 5 orang. Adapun kriteria pengguna dalam penelitian ini adalalah (1) Pengguna adalah domisili di Garut; (2) Pengguna sebagai pelaku perangkat teknologi komunikasi baik dari kalangan mahasiswa, wirausaha, akademisi dan budayawan; (3) Bersedia memberikan gambaran dan proses konversi yang di alaminya.

\section{HASIL PENELITIAN}

Pada bab ini peneliti membahas mengenai keseluruhan hasil temuan yang peneliti temukan termasuk di dalamnya tahap wawancara mendalam. Peneliti akan membahas hasil dari sudut pandang peneliti dan sudut pandang informan. Hasil penelitian ini, akan menguraikan tentang aspek motif, pengalaman, makna dan perilaku pengguna komunikasi digital.

\section{A. Motif Pengguna Komunikasi Budaya Digital}

Hasil penelitian ini, akan menguraikan tentang aspek-aspek yang terkait dengan motif pengguna komunikasi budaya digital. Berdasarkan hasil yang dilakukan, peneliti mendapatkan hasil yang beragam mengenai motif pengguna yang menggunakan komunikasi digital. Motif yang dihasilkan terbagi dalam dua kategori jenis motif yaitu motif "in order to", serta motif "karena' (because motives), artinya sesuatu merujuk pada pengalaman masa lalu individu, karena itu berorientasi pada masa lalu, yaitu dimana aktor atau seseorang merujuk pada beberapa faktor yang berkaitan dengan pengalaman masa lalu yang dilakukan oleh informan. Motif yang mendasari informan sebagai pengguna komunikasi digital dapat dilihat dalam beberapa pernyataan informan yaitu:

Saudari Silvi, Mahasiswi Fakultas Ilmu Komunikasi Universitas Garut tingkat akhir ini mengawali penggunaan media digital seperti handphone karena (because) hubungan jarak jauh dari orang tua. Namun seiring waktu, penggunaannya kini melebihi dari sekedar kebutuhan dasar berkomunikasi, fashion telah menjadi minat kewanitaannya dan berita terkini menjadi dorongan intelektualnya untuk (in order to) mengetahui perkembangan zaman tentang berbagai hal sehingga penggunaan media digital bagi Silvi tidak hanya pada handphone saja, komputer dan internet menjadi teman kesehariannya sebagai sumber penambah pengetahuannya terutama di lingkungan kampus.

karena hubungan jarak jauh dari orang tua dikasih smartphone, perangkat-perangkat lainnya untuk berkomunikasi. Sekarang beda lagi karena sudah tidak LDR dengan orang tua, jadi lebih ke mengikuti perkembangan zaman entah dari fashion, berita terkini, perkembangan negara, ya aku sedikit politisi, seputar loker-loker, wah saya tertarik lewat media itu. Banyak sih sebenarnya perkembangan zaman. kalo misalnya untuk seputar komputer, saya mungkin lebih mendeskripsikan apa yang telah saya cari, lalu saya ketik di komputer atau ga saya menggunakannya untuk berkomunikasi, terus untuk mengetahui perkembangan zaman entah itu saya melihat berita dari media online, lalu saya lebih ke Youtube untuk mencari tahu hal lainnya. 
Tidak jauh berbeda dengan rekan sekampusnya, saudari Vera, mahasiswi Fekon Uniga ini menceritakan motifnya ketika menggunakan perangkat digital selama berkomunikasi karena (because) kebutuhan, apalagi mahasiswi seperti dirinya sangat membutuhkan referensi selain buku. Kebutuhannya dipicu oleh faktor internal dirinya, sebuah komputer dan jaringan internet nirkabel menjadi penangkis rasa bosannya dengan dihibur oleh Youtube dan Online Shop. Faktor eksternal ketika dosen mewajibkan dirinya mengerjakan tugas kuliah, maka komputer dan internet dijadikan perangkat dan sumber pencarian informasi.

kalau motif saya menggunakan teknologi komunikasi baik itu smartphone dan komputer, pertama karena kebutuhan, apalagi mahasiswi seperti saya sangat membutuhkan referensi selain buku. Sedangkan smartphone menghubungkan saya dengan komunitas dan organisasi di kampus, seperti WA memudahkan saya baik dalam penggunaan instant messages dan informasi-informasi yang sesuai kebutuhan saya. Saya menggunakan komputer dan internet sebagai kebutuhan saja, kalau sedang bosan nih saya Youtube-an, online shop atau kalau sedang banyak tugas dikuliahan tuh harus selalu menggunakan bahan-bahan dari internet sebagai informasi.

Beberapa pernyataan yang telah dipaparkan, maka peneliti mengkategorisasikan beberapa motif yang disajikan dalam bentuk model komunikasi pada bagan 1 , yaitu:

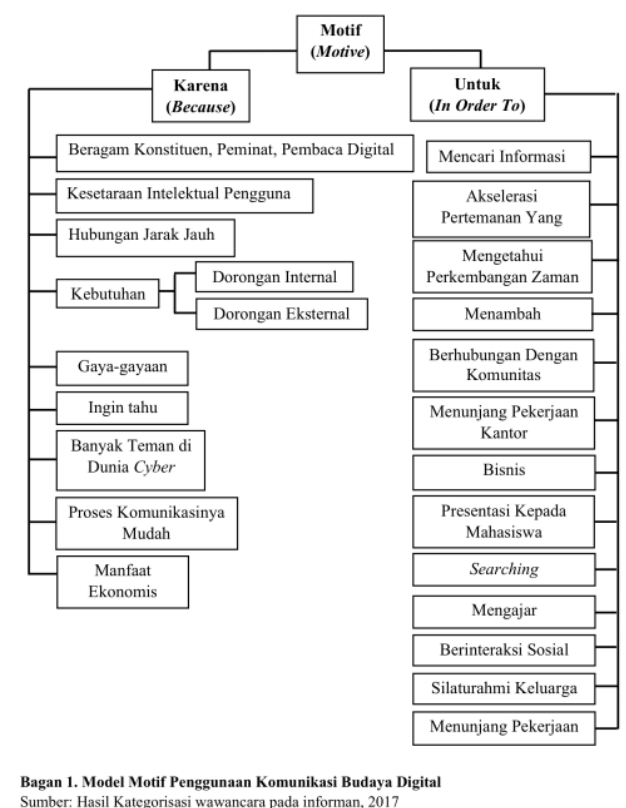

\section{B. Pengalaman Pengguna Komunikasi Budaya Digital}

Pengalaman ialah hasil persentuhan alam dengan panca indra manusia. Berasal dari kata peng-alaman. Pengalaman memungkinkan seseorang menjadi tahu dan hasil tahu ini kemudian disebut pengetahuan (Vardiansyah, 2008:3). Secara khusus, pengalaman merujuk kepada mengetahui bagaimana individu menggunakan teknologi untuk berkomunikasi, apa saja yang tersingkap, mari kita simak uraian pengalaman dari masing-masing informan berikut ini.

Diawali dengan pengalaman Bapak H. Usep Romli, Budayawan Garut mantan wartawan Pikiran Rakyat ini pernah menulis tentang dampak teknologi terhadap budaya, kesadaran intersubyektifitasnya menuturkan bahwa Undang-Undang ITE membayangi dunia kreatifitas banyak penulis seperti dirinya dengan kegamangan adanya suatu tuduhan apabila karyanya ada yang tidak sesuai menurut orang tertentu di anggap melanggar UU ITE, sedangkan dahulu penyampaian hasil karya budaya itu secara tatap-muka atau karya tulis tercetak yang dibaca oleh publik, dengan mekanisme hak jawab jika terdapat pelanggaran, tapi kini tatap-muka dan cetak fisik termediasikan oleh beragam media digital dimana karya budaya disampaikan didalamnya, sedangkan facebook itu tidak memiliki mekanisme hak jawab sehingga posisi budayawan sudah dihadapkan pada suatu tuduhan oleh UU ITE.

Budaya digital itu semacam perampasan eksistensi. Jadi eksistensi kita sebagai budayawan telah dirampas oleh teknologi. Jadi seolah-olah kehilangan keakraban manusiawi. Kalau dulu kan saya 
menyampaikan hasil budaya itu tatap muka, kalaupun tertulis tetap itu punya ...ya semacam tertulis kemudian diorasikan dipidatokan kita masih berhadapan dengan manusia, tapi ketika pindah ke facebook, pindah ke internet kita seperti menyeberang lautan yang kita ga tau itu ada apa?

Pengalaman sisi obyektifnya (noema) memandang pengaruh negatif paparan audio dan visual digital yang bebas tak terbatas pada masyarakat yang belum memiliki budaya literasi semakin menjauhkan mental masyarakatnya dari keseimbangan jiwa mereka dan menggiringnya ke dalam budaya konsumerisme, kemerosotan moral, mental dan intelektual. Bagai dua sisi mata uang, disaat yang sama berpandangan positif dari kemudahan dan keterjangkauan atas industrialisasi komunikasi berbasis aplikasi juga dapat dirasakan masyarakatnya.

Masyarakat di sini masih gemar menonton dan mendengar, nah tidak diarahkan kepada membaca/kontemplatif. Tiba-tiba datang lonjakan teknologi modern yang menyeret masyarakat itu untuk lebih menikmati media audio visual secara gampang, kalau dulu audio visual sulit kan TV cuma satu, TVRI saja. Kemudian alat-alat elektronik belum ramai dan mahal harganya. Jadi orang hanya mendengarkan siaran radio, gitu 'kan?!

Tentunya berbeda pengalaman orang tua dengan anak muda dipengaruhi oleh cara keduanya menjalani pengalamannya masing-masing. Positif atau negatifnya pengalaman yang mereka telah jalani merupakan perbedaan yang ada pada suatu waktu. Pengalaman Silvi dengan penggunaan teknologi komunikasi berbalut digital ini tentu menjadikannya lebih dekat berhubungan dengan seseorang dan pemenuhan kebutuhan lain dilakukannya melalui smartphone. Kecanduannya terhadap gadget sebagai dampak negatif yang menimpa dirinya, terlebih pengalaman buruk belanja online menyadarkan dirinya akan perbedaan grafis dengan kenyataan fisik. Pengalaman subyektifnya (noesis) mengatakan bahwa teknologi komunikasi begitu mempengaruhi seluruh kehidupannya hingga jika tanpanya, Ia akan merasakan kebutaan.

Pemahamannya tentang realitas komunikasi budaya digital didapat melalui kesadaran intersubjektifnya, dunia tempat Silvi beraktifitas dilingkupi hubungannya dengan orang lain, Ia mengatakan jika dirinya berkembang karena komunikasi, karena budaya dan karena kemajuan teknologi digital. Sehingga pengalamannya terkonstruksi menjadi tindakan yang bermakna ditunjukkan dalam kehidupan sosialnya saat Ia berkomunikasi menggunakan handphone sebagai pendukung kegiatan sehari-hari atau saat berkomunikasi teks, email dan searching menggunakan laptop yang terkoneksi dengan internet (teknologi sebagai sumber). Dalam interpretasi pengalamannya sepanjang menggunakan perangkat komunikasi digital, ia merasa (noesis) yakin bahwa teknologi ini dapat di gali untuk diketahui lagi lebih dalam dari sisi fungsi dan fiturnya, tak dapat Ia bayangkan apa yang terjadi pada bentuk dunianya ketika teknologi ini berhenti dan mati, justru fenomena komunikasi budaya digital saat ini dilihat sebagai realitas jembatan komunikasi. Beberapa pernyataan yang telah dipaparkan, maka penulis mengkategorisasikan beberapa pengalaman yang disajikan dalam bentuk model komunikasi pada bagan 2, yaitu: 


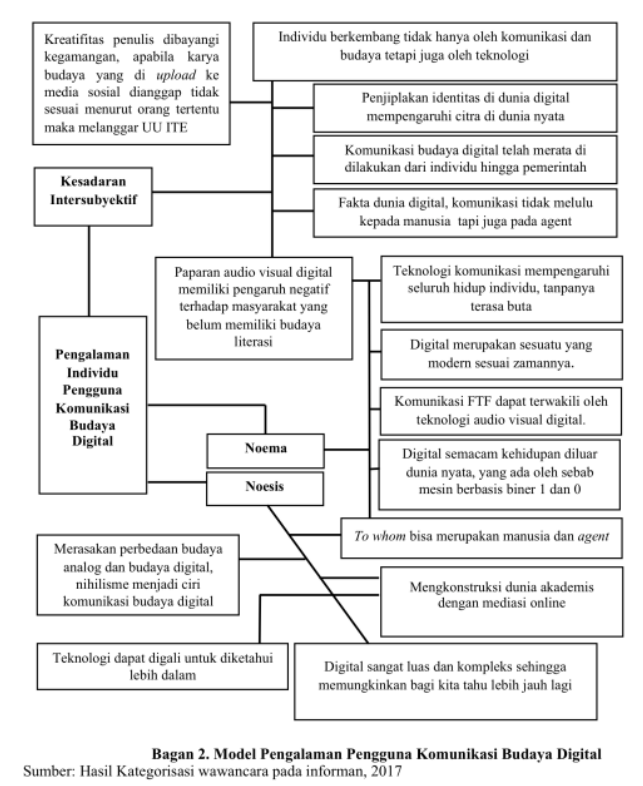

\section{Makna Pengguna Komunikasi Budaya Digital}

Makna merupakan aspek komunikasi yang tidak terlihat. Selama ini, model-model komunikasi berasumsi bahwa komunikasi merupakan pengiriman pesan dari A ke B, akibatnya perhatian utama kita berpusat pada medium, saluran, pengirim, penerima, gangguan dan umpan balik, dimana semua istilahistilah tersebut terkait dengan proses pengiriman pesan. Padahal komunikasi juga sebagai penghasil makna. Makna ada di dalam setiap benak individu melalui perspektifnya masing-masing yang tercipta dari stimuli sebuah pesan yang terdiri dari berbagai tanda yang bersifat fisik dan ditangkap oleh indera kita (Fiske, 2014:65).

Komunikasi yang berbalut budaya digital bagi individu di Kabupaten Garut telah terserap sebagai bagian dari kebudayaan maju mereka, untuk itu makna yang bagaimana yang diungkap dalam hubungannya dengan penggunaan teknologi komunikasi, menurut hasil pengamatan penulis sangat beragam, karena makna terbentuk dari berpikir, dan setiap individu memiliki kemampuan berpikir sesuai dengan kemampuan dan kapasitas kognitif atau muatan informasi yang dimilikinya. Oleh karena itu, makna tidak akan sama atas setiap individu walaupun objek yang dihadapinya sama. Pemaknaan terjadi karena cara dan proses berpikir adalah unik pada setiap individu yang akan menghasilkan keragaman dalam konstruksi makna (Juliastuti, 2000:6).

Penulis mengawali wawancaranya dengan Bapak Usep Romli, sosok yang dikenal sebagai budayawan Garut ini menuturkan makna dari komunikasi budaya digital tidak lain adalah perampasan eksistensi. Eksistensi profesi budayawan telah dirampas oleh teknologi. Jadi seolah-olah kehilangan keakraban manusiawi. Ketajaman makna yang beliau sampaikan menunjukkan bahwa komunikasi budaya digital lebih rentan nilai budayanya dan campur aduk krisis nilai komunal dengan nilai individual. Hal ini, cukup beralasan ketika hasil budaya yang disampaikan melalui komunikasi tatap-muka berpindah ke area digital yang bermakna kehilangan keakraban manusiawinya, sehingga muncul kegamangan bagi banyak budayawan untuk menghasilkan karya melalui media komunikasi digital. Sedangkan Saudari Silvi, mahasiswi Fikom Uniga aktif ini tidak suram dalam memaknai komunikasi budaya digital, dia mengatakan bahwa media komunikasi sangat bermanfaat dan bergaya hidup baru, serba praktis dan instan.

aku tuh punya statement begini, " klo tanpa perangkat aku ga bisa hidup" dengan kata lain aku harus berhubungan dengan siapa klo tidak dengan media, jadi media komunikasi sangat bermanfaat. Dengan media ini bisa berhubungan dengan teman dan lingkungan baru, gaya hidup baru mungkin, serba praktis dan instan".

Sdr. Ridwan, seorang akademisi dari STT Garut, terkesan lebih teknis dan berhati-hati dalam memaknai teknologi komunikasi digital, baginya teknologi komunikasi merupakan perangkat yang dapat 
memfasilitasi orang baik satu dengan yang lainnya atau satu dengan banyak orang untuk saling bertukar informasi. Informasi disini dengan cara berbicara, atau mengirim teks, atau mengirim video, atau apapun yang bisa dua arah.

teknologi komunikasi, kalau untuk saya teknologi komunikasi itu segala perangkat teknologi, boleh saya pecah dulu ya, kalau saya biasanya memecahkan dulu, definisi teknologi komunikasi itu terdiri dari dua bahasa. Kalau teknologi itu segala sesuatu hal yang memudahkan orang dalam bertindak sesuatu. Kalau komunikasi itu berbicara antara dua arah, kalau bisa saya sebutkan teknologi komunikasi itu adalah teknologi perangkat yang dapat mendukung atau memfasilitasi orang, baik satu dengan yang lainnya atau satu dengan banyak orang untuk saling bertukar informasi. Informasi disini dengan cara berbicara, mengirim teks atau atau mengirim video atau apapun yang bisa dua arah.

Beberapa pernyataan yang telah dipaparkan, maka penulis mengkategorisasikan beberapa makna pengguna dalam komunikasi digital yang disajikan dalam bentuk model komunikasi pada bagan 3, yaitu:

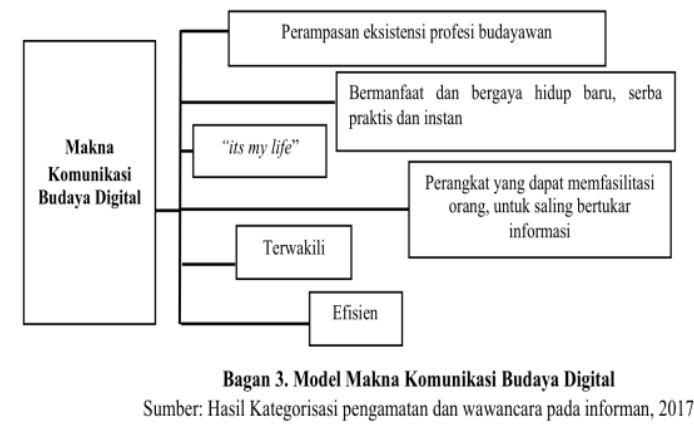

\section{Perilaku Pengguna Komunikasi Budaya Digital}

Manusia makhluk yang berbudaya, dari internalisasi budaya itu diperoleh beberapa karakteristik yang mempengaruhi perilakunya, salah satu yang menjadi fokus penelitian ini adalah artefak budayanya yaitu teknologi. Perilaku manusia dapat diklasifikasi ke dalam tiga komponen, yaitu: komponen kognitif, komponen afektif, dan komponen konatif. Komunikasi budaya digital lebih rentan nilai budayanya, karena dapat menimbulkan ekses negatif, orang bisa membuat apa saja tanpa sensor. Sementara penguna, Silvi, mahasiswi Fikom Uniga, ia menunjukkan bahwa perilakunya adalah sebagai bagian dari kebudayaan yang telah mengadopsi perangkat digital untuk berkomunikasi, seperti menggunakan smartphone yang telah tersematkan beragam aplikasi dan menggunakan komputer yang terkoneksi dengan internet. Konatif nya ditampilkan untuk menunjang aktifitas kesehariannya, baik peran sosialnya sebagai mahasiswi dengan mengakses internet untuk mencari informasi visual berupa fashion, hiburan, materi kuliah maupun perilaku mengirim e-mail smartphone untuk berhubungan dengan relasi di luar Kota Garut dan mengisi gaya hidup kekinian dengan memesan makanan melalui media. Kedewasaan afektif nya juga ditunjukkan oleh Silvi dengan mewaspadai berita hoax sebagai "sampah-sampah digital".

Berikut bagan model komunikasi terkait dengan perilaku komunikasi budaya digital terlihat pada bagan 4: 


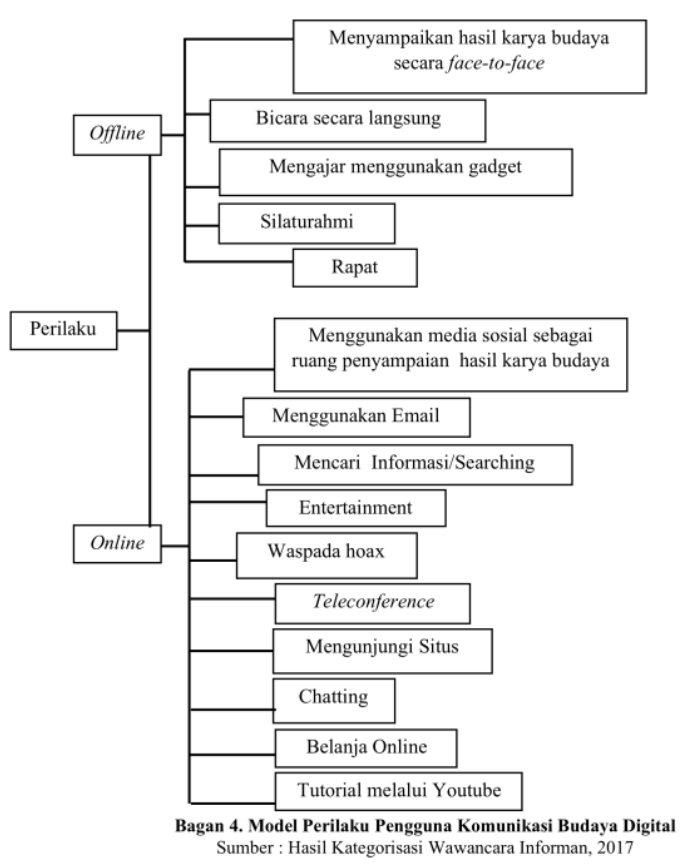

Berdasarkan hasil wawancara yang telah dilakukan, sebuah perilaku yang terealisasi pastinya memiliki alasan-alasan yang melatarbelakanginya, alasan tersebut adalah motif. Manusia secara sadar maupun tidak, memiliki motif dibalik setiap kegiatan maupun dalam setiap interaksinya. Motif merupakan pengertian yang melingkupi semua penggerak, alasan atau dorongan dalam diri manusia yang menyebabkan manusia itu berbuat sesuatu. Semua tingkah laku manusia pada hakikatnya mempunyai motif, motif manusia dapat bekerja secara sadar dan juga tidak sadar bagi diri manusia (Gerungan, 2010:151-152). Dari keseluruhan motif yang dapat di ungkap dalam hasil penelitian, hanya dua motif yang dominan yang mampu melingkupi semua motif, yaitu motif kebutuhan dan motif berhubungan. Penggunaan perangkat komunikasi digital merupakan pemenuhan kebutuhan dasar berkomunikasi. Hambatan keterhubungan antara manusia satu dengan yang lainnya secara geografis mampu diatasi dengan perangkat komunikasi digital yang tersedia baik dari segi audio maupun visual.

Pengalaman individu ketika menggunakan perangkat komunikasi budaya digital, baik yang berjenis mobile seperti smartphone maupun yang berjenis statis seperti mesin atm dan mesin informasi harga yang dilakukan Silvi serta kondisi kemajuan teknologi komunikasi kekinian memunculkan pemikiran untuk memasukkan mesin sebagai agent dari ketidakhadiran manusia lain dalam suatu peristiwa komunikasi, dilain pihak ada keinginan dari informan bahwa dunia pendidikan perlu di konstruksi dengan metode belajarmengajar dengan mediasi online. Komunikasi budaya digital telah menjadi fenomena yang menarik untuk di teliti. Pendekatan fenomenologi Schutz (dalam Kuswarno, 2009:18) adalah melihat manusia dari pengalaman subyektifnya. Melalui pendekatan ini, penulis akan mengungkapkan hal apa saja yang menjadi makna dan perilaku komunikasi budaya digital dalam konteks fenomenologis. Yang menarik untuk masuk dalam bab pembahasan adalah ketika bagaimana Bapak Rinda seorang informan dari akademisi menjelaskan realitas budaya digital sebagai bilangan biner 0 (nol) dan 1 (satu). Bilangan ini bermakna luas yang dapat mewakili apa yang ada dalam ilmu komunikasi. Bilangan terkait dengan matematika. Matematika sebagai akar ilmu komunikasi (Nina, 2013:118). Matematika adalah Bahasa yang melambangkan serangkaian makna dari pernyataan yang ingin kita sampaikan. Lambang-lambang matematika bersifat "artifisial", yang kemudian mempunyai arti setelah sebuah makna diberikan padanya. Tanpa itu maka matematika hanya merupakan kumpulan rumus-rumus yang mati”. (Suriasumantri, 2010:190). 0 (Nol) dan 1 (satu) merupakan angka dari perhitungan matematika 0 (nol) sampai 9 (Sembilan). Definisi angka 0 (nol) adalah bilangan yang habis dibagi dua, sedangkan definisi angka 1 (satu) adalah bilangan yang tidak habis dibagi dua. 0 (nol) dan 1 (satu) merupakan bilangan biner sebagai bangunan realitas digital, hal ini dapat dibuktikan melalui 
pemaknaan digital bagi komunikasi erat kaitannya dengan matematika sebagai akar ilmu komunikasi. Dari sinilah kode bilangan biner dapat merepresentasikan Perilaku Sosial dan Perilaku Teknologi.

Dalam komunikasi budaya digital dapat ditunjukkan bagaimana perilaku komunikasi termodifikasi karenanya. Dalam penelitian ini, penggunaan smartphone, komputer dan internet telah menjadi bagian perilaku masyarakat di Kabupaten Garut dalam berkomunikasi. Smartphone, komputer, internet menjadi hal yang lumrah seperti halnya media cetak koran dan media elektronik televisi. Informan yang terpilih secara sengaja oleh peneliti dengan komposisi seorang budayawan, dua orang mahasiswi dan dua orang akademisi, telah memberikan warna untuk isi penelitian ini. Secara gambaran umum, ke lima informan memberikan perbedaan perilaku berdasarkan observasi kognitif, afektif dan konatif, sehingga dari perilaku pengguna ini dapat dibedakan dua kategori generasi : (1) Digital Native, mereka yang lahir saat teknologi komunikasi sudah booming; (2) Digital Migrant, mereka yang lahir sebelum teknologi komunikasi booming.

Masing-masing perilaku pengguna, baik yang termasuk Digital Native maupun Digital Migrant memiliki variabel bawaan, seperti usia, profesi, terbuka terhadap media, aktif mencari informasi, penghiburan. Perbedaan antara budayawan dengan mahasiswa, kemudian keduanya berbeda dengan akademisi, tentu dari segi kognitif dan afektif. Ada beberapa variable kepribadian tertentu yang membuat perilaku komunikasi mereka sama, yaitu empati, kemampuan pengguna mengenali lingkungannya, dunianya menentukan perilaku dirinya sendiri, kedua adalah perilaku rasionalitas (intensitas penggunaan gadget). Sikap pengguna budayawan kita terhadap penggunaan teknologi komunikasi dipengaruhi oleh usia (status sosiokultur) sedangkan pengguna mahasiswi khususnya di Kampus Universitas Garut lebih reseptif terhadap teknologi komunikasi, mereka mau tahu cara menggunakan, mau mencari dan mau mempelajari lebih jauh lagi hingga ke masa yang akan datang.

\section{KESIMPULAN}

Terkait dengan motif, budaya digital merupakan adaptasi alamiah sejalan dengan perkembangan manusia itu sendiri dalam mengembangkan kemampuan untuk berkomunikasi ketika muncul hambatan jarak dan penglihatan dengan kondisi geografis, dan proses komunikasi berorientasi pada komunikasi bermediasi.

Bahwa pengalaman menggunakan perangkat dalam berkomunikasi dapat disimpulkan bahwa smartphone, komputer dan internet dianggap sebagai Wahana Interaktif: komputer dipandang sebagai media Computer As Medium (CAM), komputer dipandang sebagai sumber informasi bukan sekedar sarana penyampai pesan yang dibuat oleh manusia.

Pengguna perangkat komunikasi dalam memaknai komunikasi budaya digital menunjukkan keragaman makna, sehingga komunikasi digital menjadi bagian yang paling bermakna dari ekologi komunikasi.

Penyerapan teknologi dan penggunaan perangkat komunikasi begitu cepat dan luas dalam berbagai segi perilaku komunikasi, sehingga komunikasi budaya digital dipahami sebagai teknologi.

\section{Daftar Pustaka}

Creswell, Jhon W. 2002. Research Design: Qualitative \& Quantitative Approaches. Jakarta: KIK Press. Fiske, John. 2014. Pengantar Ilmu Komunikasi. Depok: PT. Raja Grafindo Persada.

Gerungan. 2010. Psikologi Sosial. Bandung: PT. Refika Aditama.

http//tekno.kompas.com/read/2015/11/19/23084827/Mau.Tahu.Hasil.Riset.Google.soal.Penggunaan.Smartph one.

http://www.cnnindonesia.com/teknologi/20150327061134-185- 2245/berapa-jumlah-pengguna-facebookdan-twitter-di-indonesia/>

Juliastuti, Nuraeni. 2000. Teori Sosiologi. Tangerang: Kharisma Publishing Group.

Kriyantono, Rachmat. 2013. Teknik Praktis Riset Komunikasi. Jakarta: Prenada Media Group.

Kuswarno, Engkus. 2009. Metode Penelitian Komunikasi Fenomenologi. Bandung: Widya Padjadjaran. 
Nurhadi, Zikri Fachrul. 2015. Teori Komunikasi Dalam Perspektif Kualitatif. Bogor: Ghalia Indonesia.

Rianto, Puji. 2016. Media Baru, Visi Khalayak Aktif dan Urgensi Literasi Media. Jurnal Komunikasi Ikatan Sarjana Komunikasi Indonesia. Vol 1(2): 90-96.

Syam, Nina Winangsih. 2013. Model-Model Komunikasi. Bandung: Simbiosa Rekatama Media.

Stellarosa, Yolanda. 2017. Woman Image in "Belanja Sampai Mati" Book. Jurnal Komunikasi Ikatan Sarjana Komunikasi Indonesia. Vol 2 (2): 97-108.

Suryana, Nana. 2008. Pola Komunikasi Masyarakat di Pedesaan dalam Era Teknologi Informasi dan Komunikasi. Observasi (Kajian Komunikasi dan Informatika) Vol. 6(2).

Suriasumantri, J.S. 2010. Filsafat Ilmu. Jakarta: Pustaka Sinar Harapan. 